\title{
Sustainability of Communication, Organizational Culture, Cooperation, Trust and Leadership Style for Lecturer Commitments in Higher Education
}

\author{
Abd. Syakur ${ }^{1}$, Tri Achmad Budi Susilo ${ }^{2}$, Wike $^{3}$, Rulam Ahmadi ${ }^{4}$ \\ ${ }^{1}$ Postgraduate Program of English Education, STKIP PGRI Sidoarjo, Indonesia \\ ${ }^{2}$ Postgraduate Programs of Education, STKIP PGRI Sidoarjo, Indonesia \\ ${ }^{3}$ Doctoral Environmental Assessments and Development, Universitas Brawijaya, Indonesia \\ ${ }^{4}$ Postgraduate Program of Public Administrations, Universitas Islam Malang, Indonesia \\ syakurabdmpd@gmail.com
}

\begin{abstract}
This reserach was focused and related to effect of sustainability communication, bureaucracy structure and public support which have significant effect toward policy implementation performance and to execute Three Dharma (education, research and comunity service) in higher education. Communication, resources, bureaucracy structure and public support has its influence against disposition. In bureaucracy structure, public support has significant effect toward its main resources which is lecturer or its teaching staff. This study aimed to analyze the effect of communication and organizational culture toward leadership style, cooperation and trust also organizational commitment of lecturer in higher education viewed from its harmonization in executing three laws. Structural equation modeling (SEM) was used to analyze causality relation between variables. This study used survey method. Population in this study was lecturers in higher education. The total sample was determined 100 respondents from elevens Institution in higher education. Result of this study showed direct and positive significant effect of communication and organizational culture toward leadership style and cooperation also trust and organizational commitment of lecturers in higher education. There was no direct and positive significant effect of communication toward organizational culture. There was direct and positive significant effect toward cooperation and organizational commitment of lecturers to Institutions in higher education. There was direct and positive significant effect of work trust toward organizational commitment.
\end{abstract}

Keywords

sustainability of communication; organizational culture; cooperation; lecturer conmitments

\section{Introduction}

Public policy was action with intention determined by actor or several actors in overcoming a problem or task (Wu et al., 2017). Public policy was meant as state wisdom, a decision meant to overcome certain problem, to conduct certain activity, or to achieve certain activity, which was done by the authorized institution as part of implementation of state's task and development

Organization was established as a place for several individuals to reach certain purpose (Sabri et al., 2011). Effectiveness of an organization would depend on the synergy or individual's cooperation and groups within organization in achieving mutual objective or target (Antonio et al., 2000; Sabri et al., 2011). Individual attitude and 
behavior within organization would be more necessary to improve organizational effectiveness which is to achieve the target determined by mutual efforts (Casimir et al., 2012). There were 4 (four) main outcome of organizational member's behavior for organization effectiveness, which are productivity, absence, turnover and job satisfaction (Vasyakin et al., 2016). These four outcomes has been reviewed in individual, group and organizational analysis unit. In individual level, factors influencing outcome has fully came from member's internal characteristic, such as demographic characteristic, personality trait, personal value and attitude, motivation and basic ability of employees (Mont and Lindhqvist, 2003).

Commitment as the feature of relationship with organization (Kerr and KaufmanGilliland, 1994). One would have high commitment toward organization if he showed: (1) strong desire to stay as member of the related organization, (2) willing to try his best for organization's interest, (3) confidence toward strong acceptance of organization values and objectives (Alonderiene and Majauskaite, 2016). Effort to build commitment was describe as an effort to build a long term relationship (Casimir et al., 2012). Employee who has commitment to the organization would probably last longer than not committed employee (Casimir et al., 2012; Kerr and Kaufman-Gilliland, 1994).

Organizational commitment divide into three dimensions, which are: affective, continuance and normative (Mont and Lindhqvist, 2003). Affective commitment came from emotional or psychological attachment with the organization. Continuance commitment based from one's judgment who has been investing his resource, personal capacity (knowledge and skill) to the organization, thus it would be risky/costly if he was to leave the organization. Normative commitment was based on morality motive, in which individual was morally responsible to be loyal toward organization (Gayle et al., 2011). As addition to affective components developed to approach of these three components showed that continuance and normative commitment is part of attitudinal commitment (Ruppel and Harrington, 2000). Continuance commitment was based on pragmatic assessment of employees concerning cost and benefit of staying within the organization and normative commitment was based on moral obligation or responsibility toward the organization (Azis and Kurniawan, 2019; Vasyakin et al., 2016). There were four factors affecting one's commitment to the organization, such as: 1) investment, 2) reciprocity, 3) lack of alternatives and 4) identification (Ruppel and Harrington, 2000). The organizational commitment is not just loyalty to the organization, but it is also a continuous process in which employees express their concern to the organization in the form of success and high achievement (Kerr and Kaufman-Gilliland, 1994). Having committed employees would bring benefit to the organization, such as developing extra role behavior (ERB) which is an innovative and positive spontaneous attitude for organization, beyond normal attitude that based on the urge to obtain return (Alonderiene and Majauskaite, 2016).

Several empirical study proved that job satisfaction is an important antecedent from organizational commitment. From another side the commitment is a mediator for job satisfaction in affecting performance (Casimir et al., 2012). Based on theoretical explanation above, hypothesis can be made that performance was affected by efforts, efforts was affected by organizational commitment, and organizational commitment was affected by job satisfaction (Ruppel and Harrington, 2000). More review on the literature of organizational behavior and empirical study showed that important factor to affect job satisfaction and organizational commitment was leadership effectiveness and communication within organization (Mont and Lindhqvist, 2003). As an attitude, difference between organizational commitment and job satisfaction can be seen from several perspectives. Organizational 
commitment is a global response toward a job or several aspects of a job. Job satisfaction is an attitude to a condition related with certain job and one aspect of the job (Sabri et al., 2011).

The organization behavior has the essence of three leadership study approaches, such as trait, behavior and contingency. The leadership is not certain position, but a complex process which involve interaction between leader, external environment and subordinate. Based on this view, leadership was defining as the process which affect organized group which directed to organizational objectives achievement (Kerr and Kaufman-Gilliland, 1994; Ruppel and Harrington, 2000). Several empirical studies in business and non-business organization discover that leadership effectiveness has positive impact toward attitude and behavior of organization's members. The employee who considers his superior to have poor leadership practice would cause higher tendency for the employee to leave the organization, low job satisfaction, and high work stress. This study's result supports the hypothesis that leadership effectiveness has significant effect toward job satisfaction, stress and organizational commitment (Hegger et al., 2012).

Other than leadership aspect, to strengthened job satisfaction and build employee's commitment, communication aspect within group was also considered as an important factor. Organizational communication has important role to support organizational operational effectiveness. Important aspect of organizational communication is the potential of this communication to act as tool designed by management to achieve firm's objectives. The importance of communication can also be seen from its benefit for organization which covers control and monitoring function, motivation, emotional disclosure, and information availability for decision making (Azis and Lestariningsih, 2018; Ruppel and Harrington, 2000).

Communication occur within group was a fundamental mechanism to show their disappointment or satisfaction. Communication would suggest emotional expression from one's feeling and social needs fulfillment. Last function of communication regarding its role was to facilitate decision making. Mainstream communication study within organization would particularly relate with its impact toward outcome for individual and organization. Empirical study found out that communication effectiveness was the antecedent of overall job satisfaction, employees commitment to organization, absence and turnover, and job productivity also information ambiguity reducer for subordinate (Azis and Lestaringingsih, 2018; Kerr and Kaufman-Gilliland, 1994).

Being aware about contribution of organizational commitment as an important indicator of organizational success, this study aimed to review relationship of several factors, either directly or indirectly, which affect organizational commitment. Organizational behavior study was mostly done in business organizational context thus generalization of organizational behavior constructions would be limited. It was also known that higher education has typical characteristic, different than business organization, particularly in its system and structures. However, viewed from organizational behavior theory perspective, substantially each organization would always try to achieve organization objectives. This study review and reexamine outcomes from organizational member's behavior. With more comprehensive conceptual framework, it was expected that this study could bring more comprehensive result regarding effect of leadership and organizational communication toward job satisfaction and organizational commitment (Ruppel and Harrington, 2000). Theoretically, there were empirical justification that it was expected that there were strong and causal relationship between leadership and organization communication toward job satisfaction and organizational commitment. Besides, theories concerning leadership, communication, job 
satisfaction and employee's commitment have give support over the justification. Therefore, theoretical testing in empirical situation should be supported.

The leadership is a process that affects organized groups which direct to achieve organizational objectives as the appropriate base to measure leadership construction. (Sabri et al., 2011) used eight indicators to measure leadership construction which called Leadership Effectiveness Index such as: competence, fair treatment, work climate, superior ideas, attention, subordinate involvement, cooperation, and opportunity to interact. Organizational communication is satisfaction of organizational member toward several communication aspects occurs within organization. Variable indicator of organizational communication would include organization perspective, personal feedback, organizational integration, direct superior communication, communication climate, horizontal communication, media quality and subordinate communication.

Job satisfaction is attitude which reflects happy feeling of lecturer or teaching staff to go to work. Variable indicator for job satisfaction is compensation, promotion and monitoring. Organizational commitment was define as employee's attachment toward organization. Organization commitment was measured in three dimensions of affection commitment, continuance commitment and normative commitment. The Hypothesis in this study were:

H1: Communication has direct and significant effect toward organizational culture and leadership,

$\mathrm{H} 2$ : Organizational culture has direct and significant effect toward organization commitment,

H3: Leadership has direct and significant effect toward organizational communication,

H4: Leadership has direct and significant effect toward organizational culture,

H5: Leadership has direct and significant effect toward organization commitment,

H6: Work climate has direct and significant effect toward organization commitment,

H7: Leadership has indirect and significant effect toward organization commitment through organizational sustainable communication mediation,

H8: Leadership has indirect and significant effect toward organization commitment through job satisfaction mediation,

H9: Leadership has indirect and significant effect toward organization commitment through organizational communication and job satisfaction mediation.

\section{Research Methods}

Research design this study used quantitative approach. East java as a study site was chosen due to its potential as a rapidly developed city of education. Population in this study was eleventh Institution of higher education and 100 permanent lecturers in higher education. Sample selection was done in two phases; first one was taking purposive sample in higher education, to obtain eleventh higher education: Madura Islamic University, Universty of Nahdlatul Ulama Blitar, University of Kartini Surabaya, Institut Agama Islam Annuqoyah (INSTIKA) Sumenep, Institut Sains dan Teknologi Annuqayah (IST) Sumenep, STKIP PGRI Sidoarjo, Stisospol Waskita Dharma Malang, STIE Al-anwar Mojokerto, STIE IEU Surabaya, STAI Darul Ulum Banyuangi, STIKES RS Anwar Medika. Second phase is sample selection of each selected Institution in higher education by simple random sampling. Number of sample chosen from each Institution was 20 lecturers based on (a) SEM sample guideline is 50-100 samples, (b) number of indicator used in all latent variable times to 5-10 (Ferdinand, 2000). In this study, indicator of study use 22 indicators thus number of sample was between 55-110 respondents. Number of sample was determined to be 100 samples. Respondent selection was using probability sampling technique with systematic random 
sampling. Sample for this study was chosen through probability and certain system which regulate random sample selection for first data and subsequent data using certain interval. Data collection was done simultaneously for all selected in higher education of east java Indonesia.

Study variable consist of exogenous and endogenous variables. Exogenous variable is leadership (X1). Endogenous variable are organizational communication (Y1), Cooperation and job satisfaction (Y2) and trust and organizational commitment (Y3). data analysis method used to answer the hypotheses is Structural Equation Modeling or SEM with AMOS 4.0.

\section{Discussion}

\subsection{Respondent Characteristics}

Respondent was 100 people, representing elevent selected in higher education of east java Indonesia. Respondents consist of $56 \%$ male and $44 \%$ female. Ages of respondents consist of less than 30 years old (26\%), 30-39 years old (30\%), 40-49 years old (35\%) and more than 49 years old $(10 \%)$. Respondent's level of education consist of undergraduate (46\%), Magister (graduate) (53\%) and Doctoral (graduate) (2\%). Respondent's status of marriage consists of $15 \%$ not married and $85 \%$ married. SEM Analysis. Theoretical model in this study's conceptual framework would be fit if supported by empirical data. To found out whether hypothetical model was supported by empirical data or not, we conduct goodness of fit overall model test. Several results of the test was presented in Table 1 below.

Table 1. Goodness of Fit Overall Model Testing in Initial Phase

\begin{tabular}{|l|c|c|c|}
\hline Goodness of fit & Result & Cut-off & Description \\
\hline chi square & 155,963 & Small & \\
\hline P & 0,116 & $>0,05$ & Good model \\
\hline RMSEA & 0,033 & $\leq 0,08$ & Good model \\
\hline GFI & 0,910 & $\geq 0,90$ & Good model \\
\hline AGFI & 0,832 & $\geq 0,90$ & Less Good Model \\
\hline CFI & 0,993 & $\geq 0,94$ & Good model \\
\hline chi square/df & 1,147 & $\leq 2$ & Good model \\
\hline
\end{tabular}

\subsection{Result of Hypotheses Testing}

This hypotheses testing was done using t-test. Hypotheses in this study consist of relationship between variables and thus tested by partially looking at each influential path in SEM analysis results. Meanwhile, test for indirect influence was derivation of direct influence test. Result for hypothesis testing analysis was given in Table 2.

Table 2. Result of Hypothesis Testing

\begin{tabular}{|l|l|l|c|c|c|c|c|}
\hline $\mathbf{H}$ & $\begin{array}{l}\text { Variable } \\
\text { Independent }\end{array}$ & $\begin{array}{c}\text { Variable } \\
\text { dependent }\end{array}$ & $\begin{array}{c}\text { Standar- } \\
\text { dization }\end{array}$ & P-value & Description & $\begin{array}{c}\text { Intervention } \\
\text { Variable }\end{array}$ & $\begin{array}{c}\text { Path } \\
\text { coefficient }\end{array}$ \\
\hline $\mathrm{H} 1$ & Leadership $\left(\mathrm{X}_{1}\right)$ & $\begin{array}{l}\text { Organizational Com. } \\
\left(\mathrm{Y}_{1}\right)\end{array}$ & 0,97 & 0,000 & Significant & - & directly \\
\hline $\mathrm{H} 2$ & Leadership $\left(\mathrm{X}_{1}\right)$ & $\begin{array}{l}\text { Job Satisfaction } \\
\text { (Y2) }\end{array}$ & 0,09 & 0,523 & Non-Significant & - & directly \\
\hline $\mathrm{H} 3$ & Leadership $\left(\mathrm{X}_{1}\right)$ & $\begin{array}{l}\text { Organizational } \\
\text { Commitment }\left(\mathrm{Y}_{1}\right)\end{array}$ & 0,46 & 0,000 & Significant & - & directly \\
\hline
\end{tabular}




\begin{tabular}{|c|c|c|c|c|c|c|}
\hline $\begin{array}{c}\mathrm{H} 4 \mid \begin{array}{l}\text { Organizational } \\
\text { Com. }\left(\mathrm{Y}_{1}\right)\end{array}\end{array}$ & $\begin{array}{l}\text { Job Satisfaction. } \\
\left(\mathrm{Y}_{2}\right)\end{array}$ & 0,46 & 0,000 & Significant & - & directly \\
\hline $\begin{array}{c}\text { H5 } \begin{array}{l}\text { Organizational } \\
\text { Com. }\left(\mathrm{Y}_{1}\right)\end{array}\end{array}$ & $\begin{array}{l}\text { Organizational } \\
\text { Commitment (Y) }\end{array}$ & 0,30 & 0,000 & Significant & - & directly \\
\hline $\begin{array}{l}\text { H6 Job Satisfaction } \\
\left(\mathrm{Y}_{2}\right)\end{array}$ & \begin{tabular}{|l|} 
Organizational \\
Commitment (Y)
\end{tabular} & 0,31 & 0,000 & Significant & - & directly \\
\hline H7Leadership $\left(\mathrm{X}_{1}\right)$ & $\begin{array}{l}\text { Organizational } \\
\text { Commitment (Y) }\end{array}$ & 0,29 & - & Significant & $\begin{array}{l}\text { Organizational } \\
\text { Commitment } \\
\left(\mathrm{Y}_{1}\right)\end{array}$ & Indirect \\
\hline H8Leadership $\left(\mathrm{X}_{1}\right)$ & $\begin{array}{l}\text { Organizational } \\
\text { Commitment (Y) }\end{array}$ & 0,03 & - & Non- Significant & $\begin{array}{l}\text { Job } \\
\text { Satisfaction } \\
\text { (Y2) }\end{array}$ & Indirect \\
\hline
\end{tabular}

\subsection{Discussion}

Based on SEM analysis result, we obtain hypothesis testing result for Hypothesis 1, leadership has significant effect toward organizational communication, which was accepted. We obtain 0,97 coefficient and 0,000 $p$ value. It means that there was positive and significant effect of leadership variable toward the latest national news, that more communication and cooperation would increase leadership of permanent lecturers in higher education to conduct three dharma (education, research and comunity service) of higher education. In this study, leadership was reflected in eight indicators, such as competence, fair treatment, work climate, superior ideas, attention, subordinate involvement, cooperation and opportunity to interact. Meanwhile, organizational communication would be reflected in eight indicators, such as organization perspective, personal feedback, organization integration, direct superior communication, organization climate, horizontal communication, media quality and current news update.

Results obtain in this study showed support toward study which stated that participative leadership approach could improve organizational commitment. Leadership is the main activity to achieve organization's objectives (Kerr and Kaufman-Gilliland, 1994). Leadership is the ability to influence others so that they are willingly work together to achieve organization's objectives. This effort cannot be viewed as an independent effort since leadership could occur if there is leader and people to lead also interaction or communication between both sides. Other researcher, (Antonio et al., 2000) showed connection between internal communication and leadership. Other than leadership aspect, to improve job satisfaction and build employee's commitment, communication in group was considered as an important factor too. Organizational communication has important role to support organizational operational effectiveness. Important aspect from organizational communication is the potential of communication itself as a tool to be designed by management in order to achieve organization's objectives.

Importance of sustainability communication can also be seen from its benefit for organization which consists of control function (control and monitoring), motivation, emotional disclosure, and information availability for decision making (Wu et al., 2017). Communication act to control member's behavior. Each organization has authority hierarchy and formal guidelines that should be obeyed by employees such as, employees were asked to communicate their complaint regarding their job to their direct superior. According to its job description, or along with company policy, communication can run control function. Other than this, informal communication also controls behavior. 
Communication would help motivation development by explaining to lecturers about what to do, whether they have been working well and what can be improved if their performance was under the basic standard. For lots of employees, work group is the first source of social interaction. Communication occur within the group is the fundamental mechanism in showing disappointment or their satisfaction (Kerr and Kaufman-Gilliland, 1994). Communication suggests emotional disclosure from feeling and social needs fulfillment. Last function related with communication was its role in facilitate decision making. Communication provides the necessary information for individual or group to make decision and forwarding data to recognize and assess alternative option.

None of these four functions should be seen as one more important than the others. To have effective performance, group should maintain several control toward its member, stimulate members to show performance, provide facility for emotional disclosure, and making decisions. Almost all communication interaction within a group or organization would run one or more functions from these four functions. Through communication, all party could share information, reduce doubt, information inclarity, hesitation, and negative prejudice. Important impact of communication is its potential to grow trust and nurture partnership commitment between parties within the system.

Hypothesis 2 which states that leadership has significant effect toward job satisfaction was rejected. 0,09 coefficient and 0,523 $p$ value were obtain in this study. This means there is no positive and significant effect of leadership toward job satisfaction. It describe that leadership process which was mostly needed in organization still have not run well thus it cannot give direct impact toward job satisfaction of permanent lecturers. Current leadership was still unable to give motivation toward subordinate or permanent lecturers. A leader or manager who deal with managerial task would always in contact with the task to motivate their subordinate since position wise, a manager work through its subordinate. Therefore, understanding motivation in the context of organizational behavior became very important for leaders or managers who want to achieve organization's objectives. The point is leadership was needed to move, direct and maintain behavior of organization member (subordinate) to achieve better result or performance from time to time, either in individual or organization context.

Hypothesis 3 which state that leadership has significant effect toward organization commitment was accepted. We obtain 0,46 coefficient and $0,000 p$ value. This means that there is positive and significant effect from leadership toward organizational commitment, better leadership would improve organizational commitment of permanent lecturers. This direct and significant relationship can be explained based on leader's point of view. Result of this study showed that competence and experience of leaders has able to improve the commitment of permanent lecturers in higher education of east java Indonesia. Commitment of permanent lecturers in higher education of east java Indonesia was showed by the willingness of permanent lecturers to keep working for higher education of east java Indonesia.

Hypothesis 4 which state that organizational communication has significant effect toward job satisfaction was accepted. We obtain 0,9 coefficient and $0,000 p$ value. There was positive and significant effect of organizational communication variable toward job satisfaction, in which the developing organizational communication would improve job satisfaction. In Institution' service range, communication would encourage motivation by explaining toward permanent lecturers about what to do and how to work well. Leader unit and relationship of permanent lecturers was initiated by good communication within work groups. For many permanent lecturers, work group is the first source of social interaction. Communication within work group is the fundamental mechanism in showing 
disappointment or satisfaction of permanent lecturers. Communication suggests emotional expression from feeling and social needs fulfillment. Other benefit related with the role of communication for decision making in Institution is that good communication would inform member or leader to make decisions. Communication would provide the necessary information for individual and group to make decision and forwarding data to recognize and assess alternative option.

Permanent lecturers should maintain communication between work unit, communication climate horizontal communication such as one another and subordinate communication which has already run well. Leader should assure that almost all communication interaction occur in Institution has run well. Through communication, all parties could share information, reduce doubt, information in clarity, and negative prejudice. Important impact of communication would be its potential to grow trust and partnership between the existing organizational members within Institution system. Creating effective communication between leader and permanent lecturers has been used by permanent lecturers as the reason to be satisfied with their works. Willingness of manager to listen, understand and acknowledge the opinion or achievement of employees has the important role to create job satisfaction. Job satisfaction of permanent lecturers has become the main factor of communication in structure of permanent lecturers in higher education of east java Indonesia. Through communication, leaders could discover the need, the desire and expectation of permanent lecturers in implementing of higher education by evaluating and improving quality of the existing communication media. With optimum communication, Institution should think and review about any factors to be improved and continuously fixed so that it could affect job satisfaction of permanent lecturers.

Hypothesis 5 which state that organizational communication has significant effect toward organization commitment was accepted. We obtain 0,30 coefficient and 0,000 p value in this study. This means that there is positive and significant effect from organization communication variable toward organizational commitment, in which improved organization communication would improve organizational commitment. In the context of colleges' institution, communication is the key of higher educations' stability. Lecturer would conduct better communication with their superior, coworker or with their students. Communication would work well between leader and subordinate and causing three dharma can be implemented in excellent manner. Good communication would cause lecturers and its surrounding to feel at home and working with high motivation and passion. This condition would improve lecturer's commitment toward organization.

Hypothesis 6 which state that cooperation climate has significant effect toward organization commitment was accepted. We obtain 0,31 coefficient and $0,000 p$ value. There was positive and significant effect from cooperation climate toward organizational commitment, in which better cooperation climate would improve organizational commitment. One of the factors related with job satisfaction of permanent lecturers in higher education of east java Indonesia, which finally could affect organizational commitment directly, was cooperation climate with compensation and promotional system.

Hypothesis 7 state that leadership has direct and significant effect toward organization commitment through organizational communication mediation. We obtain 0,29 coefficient in this matter. There was positive and significant effect from leadership to organizational commitment variable through organization communication mediation. Improved leadership in an organization would cause organizational commitment to improve and mediated by organization communication. The role of a good leader would cause better relationship or communication within the organization (Kerr and Kaufman-Gilliland, 1994; Ruppel and Harrington, 2000). 
Good communication between leader and subordinate would cause business process in higher education cannot run well. Good communication would make lecturers feel at home and work with high motivation and passion. This condition showed that leadership process can improve organization communication, which in turn would improve permanent lecturer's commitment toward institutional organization in higher education of east java Indonesian (Kerr and Kaufman-Gilliland, 1994; Ruppel and Harrington, 2000)..

Hypothesis 8 state that leadership has direct and significant effect toward organization commitment with cooperation climate and mediated by job satisfaction was accepted. We obtain 0,03 coefficient value in this testing. There is no positive and significant effect of leadership toward organization commitment variable mediated by job satisfaction. Leadership cannot improve organization commitment if its members did not feel satisfied about their job. A responsible leader would be able to assure compensation, promotion and fair monitoring to increase job satisfaction which in turn would improve member's commitment.

Hypothesis 9 state that leadership has direct and significant effect toward organization commitment through job satisfaction and organizational communication mediation was accepted. We obtain 0,47 coefficient value in this matter. There was positive and significant effect from leadership toward organization commitment through organizational communication and cooperation mediation. Process to improve leadership would also improve organization commitment mediated by organizational communication and job satisfaction.

A good leader would take the role in leading better organizational communication. Communication process would run smoothly, either between organizational member also between leader and member of organization. A good relationship has the direct effect toward job satisfaction. Leader capable of communicating all direction toward members of his organization would indirectly, able to deliver job satisfaction (Kerr and Kaufman-Gilliland, 1994; Ruppel and Harrington, 2000). Eventually, such leader would be able to create attachment and reduce willingness of member to leave or move to another organization. Leader should be able to influence members so that they could gain higher optimism, selfconfidence and commitment toward objectives and mission of organization. Leader should possess good communication ability to satisfy member of organization. Therefore, in directing his behavior, leader would be able to affect organization commitment. 


\section{Conclusion}

This study discovers that important factors to affect organization commitment were leadership and organizational sustainability communications each other. Organizational communication and work climate also job satisfaction would all together become mediator for leadership to influence organization commitment. For subsequent study, it was expected that study object should be broadened to all parts of Indonesia. Study for various parts of Indonesia would meet with various social political, economy and cultural background and thus might form different behavior pattern. Subsequent study should also done to develop this model by involving the people as social user in Institution context and to develop study variables related with people as consumers to obtain more complex result.

\section{References}

Alonderiene, R., and Majauskaite, M. (2016). Leadership style and job satisfaction in higher education institutions. International Journal of Educational Management.

Antonio, A. L., Astin, H. S., and Cress, C. M. (2000). Community service in higher education: A look at the nation's faculty. The Review of Higher Education 23, 373-397.

Azis, R., and Kurniawan, D. (2019). Strategi Peningkatan Kemampuan Peternak Itik Melalui Pelatihan Manajemen Pakan Itik Terhadap Kelompok Peternak Itik Hibrida Super di Desa Slorok Kecamatan Doko Kabupaten Blitar. Jurnal Pengabdian dan Pemberdayaan Nusantara (JPPNu) 1, 25-31.

Azis, R., and Lestaringingsih, L. (2018). Pelatihan Pengolahan Nugget Sayuran Untuk Meningkatkan Produktivitas Anggota Pendamping Keluarga Harapan Di Desa JatinomBlitar. Briliant: Jurnal Riset dan Konseptual 3, 230-236.

Azis, R., and Lestariningsih, L. (2018). Pelatihan Managemen Budidaya Itik untuk Meningkatkan Produksitivas Kelompok Ternak di Desa Slorok Kecamatan Doko Kabupaten Blitar. Briliant: Jurnal Riset dan Konseptual 3, 436-442.

Casimir, G., Lee, K., and Loon, M. (2012). Knowledge sharing: influences of trust, commitment and cost. Journal of knowledge management.

Gayle, D. J., Tewarie, B., and White Jr, A. Q. (2011). "Governance in the Twenty-firstcentury university: Approaches to effective leadership and strategic management: ASHE-ERIC Higher Education Report," John Wiley \& Sons.

Hegger, D., Lamers, M., Van Zeijl-Rozema, A., and Dieperink, C. (2012). Conceptualising joint knowledge production in regional climate change adaptation projects: success conditions and levers for action. Environmental science \& policy 18, 52-65.

Kerr, N. L., and Kaufman-Gilliland, C. M. (1994). Communication, commitment, and cooperation in social dilemma. Journal of personality and social psychology 66, 513.

Mont, O., and Lindhqvist, T. (2003). The role of public policy in advancement of product service systems. Journal of Cleaner Production 11, 905-914.

Ruppel, C. P., and Harrington, S. J. (2000). The relationship of communication, ethical work climate, and trust to commitment and innovation. Journal of business Ethics 25, 313328.

Sabri, P. S. U., Ilyas, M., and Amjad, Z. (2011). Organizational culture and its impact on the job satisfaction of the University teachers of Lahore. International Journal of Business and Social Science 2.

Vasyakin, B. S., Ivleva, M. I., Pozharskaya, Y. L., and Shcherbakova, O. I. (2016). A Study of the Organizational Culture at a Higher Education Institution [Case Study: Plekhanov 
Russian University of Economics (PRUE)]. International Journal of Environmental and Science Education 11, 11515-11528.

Wu, X., Ramesh, M., Howlett, M., and Fritzen, S. A. (2017). "The public policy primer: managing the policy process," Routledge. 